DOI https://doi.org/10.30525/978-9934-26-074-2-6

\title{
АЛЬТЕРНАТИВНЕ ВИРІШЕННЯ СПОРІВ: СУТНІСТЬ ПРОЦЕСІВ, ОСНОВНІ ГРУПИ ТА ВИДИ
}

\author{
Пушкіна О. В. \\ доктор юридичних наук, професор, \\ завідувачка кафедри ицвільного, господарського та екологічного права \\ Національного технічного університету «Дніпровська політехніка» \\ Махова Л. О. \\ адвокат, \\ старший викладач кафедри ичивільного, \\ господарського та екологічного права \\ Національного технічного університету «Дніпровська політехніка» \\ м. Дніпро, Україна
}

На комунікаційному рівні все частіше спостерігається загострене ускладнення соціальних відносин, що неминуче породжує конфлікти у політичній, економічній, соціально-побутовій сферах. Саме це і є мотивуючим поштовхом пошуку ефективних та дієвих альтернативних засобів мирного врегулювання суперечливих ситуацій, зокрема у системі права, що врахують нюанси та індивідуальні потреби сторін, дозволять дотриматися балансу інтересів, стримати ескалацію конфлікту та превентивно не дозволять суперечці перетворитися в затяжну конфронтацію. До числа таких інструментів сміливо можна віднести, стрімко набираючий позитивну історію, інститут альтернативного вирішення спорів, у якому природньо закладено потужний ресурс гармонізації інтересів шляхом досягнення компромісного консенсусу, що екологічно може стати невід'ємною частиною і правової практики України.

Термін «альтернативне вирішення спорів» (Alternative Disput Resolution) (далі - ABC), вперше почали використовувати в США для позначення компромісних і неформалізованих процедур врегулювання конфліктів.

Альтернативними визнаються лише такі способи $\mathrm{ABC}$, які мають консенсуальний характер i обов'язково передбачають участь нейтральних, незалежних професіоналів у розв'язанні суперечки.

У вітчизняній та зарубіжній юридичній літературі відсутнє єдине розуміння категорії «альтернативне вирішення спорів.» Це поняття може 
бути представлено і в широкому значенні - як право вибору будь-якого, не забороненого законом, способу вирішення спору.

Існують різні методи (підходи) з вирішення конфліктів, які умовно можна розділити на дві групи: традиційні (вирішення спорів 3 позиції права, шляхом використання законодавчих норм в судах) і нетрадиційні (т.з. «альтернативні» - вирішення спорів з позиції пошуку компромісних рішень, згоди між конфліктуючими сторонами за допомогою 3-ї незалежної сторони).

Альтернативні способи вирішення спорів об'єднує договірна основа їх створення, добровільність використання, оскільки це право, а не обов'язок особи. Їм властива загальна мета: мирне врегулювання спору, досягнення компромісу і збереження партнерських відносин між учасниками [1, с. 54].

Альтернативне вирішення $є$ цілком реальним і життєздатним механізмом вирішення правових спорів, на користь цього свідчить і світовий досвід. Використання АВС обумовлено об'єктивними факторами, серед яких: необхідність спрощення процедури вирішення спорів, використання існуючих методів примирення для подолання юридичних конфліктів, необхідність звільнення судових органів від перенавантаження.

Всю гаму уявлень про сутність категорії «альтернативне вирішення спорів» можна умовно звести до трьох основних груп.

До першої групи належить поняття, що альтернативне вирішення спорів - це альтернатива державному правосуддю. Даний варіант трактування АВС включає в себе всі несудові способи вирішення спорів та врегулювання конфліктів (переговори, посередництво, примирення, арбітраж тощо).

Відмінності АВС від державного судочинства полягають у суб’єктному складі учасників правовідносин; у підставах виникнення правовідносин; у взаємовідносинах між сторонами та особами, які сприяють вирішенню спору чи врегулюванню конфлікту; у порядку залучення осіб, які сприяють вирішенню ситуації; в змісті правовідносин - порядку розгляду та вирішення справ, врегулюванні розбіжностей сторін; в можливостях примусового виконання акту, яким досягається процесуальний результат [2].

Друга група альтернативного вирішення спорів -це способи регулювання конфліктів, засновані тільки на досягненні компромісу - це переговори, посередництво (медіація), примирення. Існує кілька процесуальних методів АВС, пов'язаних 3 якісними особливостями окремих способів, використовуваних для досягнення необхідного результату: метод вирішення спорів (винесення рішення); застосування норм права (змагальний); регулювання конфлікту та узгодження 
інтересів (пошук компромісу); рекомендаційний (експертна оцінка); змішаний (комбінований) метод.

Третю групу утворюють уявлення про альтернативне вирішення спорів як комбінування способів (наприклад, переговори посередництво, посередництво - арбітраж, арбітраж - посередництво (медіація), примирення тощо) або моделювання спеціального (власного) способу вирішення спорів і врегулювання конфліктів, виходячи 3 конкретних обставин і інтересів сторін.

$\mathrm{ABC}$ - процес без звернення до формальної системи судочинства:

Переговори або негоиіація (negotiation) - врегулювання економіко правового спору безпосередньо сторонами без втручання інших осіб.

Aрбітраж (arbitration) - це процес, у ході якого дві сторони зустрічаються в присутності нейтральної третьої особи, яка є спеціально підготовленим арбітром, вислуховує сторони, виносить обов'язкове або необов'язкове для виконання рішення, залежно від того, про що сторони домовились заздалегідь. Фактично арбітраж створює приватну судову систему. Якщо одна із сторін не бажає дотримуватися умов рішення, змусити можна через державний суд. Міжнародний арбітраж використовується, коли сторони або предмет спору знаходяться в різних юрисдикціях. Сторони домовляються до якого міжнародного арбітражного суду вони звернуться у разі суперечки.

Найбільш поширеним процесом залишається посереднищтво або медіація (mediation) - врегулювання конфлікту на основі переговорів за участю нейтральної особи (посередника) з метою укладення обов'язкової для сторін угоди щодо спору. Третя особа не має повноважень для ухвалення рішення.

Основними принципами медіації є добровільність, конфіденційність, правомочність сторін, щирість намірів щодо вирішення, компромісність, неупередженість посередника, неформальність та гнучкість процедури тощо.

Перевагами медіації є те що, сторони безпосередньо беруть участь у процесі врегулювання спору; посередник може розглянути спір об'єктивно і допомогти сторонам у визначені способів вирішення, які вони, можливо, не застосували самостійно; економія часового та економічного ресурсу, оскільки посередництво може бути застосовано на ранній стадії спору, врегулювання його може відбутися значно швидше, ніж в суді; зниження вартості процесу вирішення спору (без судових та арбітражних витрат); можливість збереження партнерських стосунків після розв'язання суперечки; можливість впливати на результат; конфіденційність процедури; запобігання виникненню подібних конфліктів у майбутньому; психологічний комфорт, гарантія добровільного виконання рішення у разі вдалої медіації. 
Альтернативне вирішення спорів має безперечні переваги, однак, незважаючи на позитивні риси АВС, існують обставини, що і обмежують їх застосування. До них можна віднести: 1) альтернативні форми не підходять для спорів щодо складноправових питань. Альтернативне вирішення спорів більше застосовуєтся в питаннях встановлення фактів, але не права; 2) у спорах 3 множинністю сторін альтернативні засоби можуть виявитися неефективними в силу їх консенсуальної природи, так як важко домогтися угоди між двома сторонами і майже неможливо при багатосторонності; 3) для застосування альтернативних засобів необхідно наявність бажання сторін співпрацювати. Тому в разі відсутності бажання контактувати один 3 одним $\mathrm{ABC}$ неможливо, а, отже, неможливо домогтися вирішення спору і захисту своїх прав і інтересів; 4) зацікавленість учасників спору в можливості збереження права апеляції судового рішення або в приверненні суспільної уваги до тієї чи іншої проблеми, чи, нарешті, в необхідності затягування вирішення спору, коли однією зі сторін вигідна відстрочка в його вирішенні [3; c. 109].

Висвітлені недоліки не є обов'язковими для $\mathrm{ABC}$, але визнання та врахування їх ймовірності може слугувати ефективним превентивним заходом від помилок та можливість чіткого формалізованого регламентування.

Сьогодні Україна перебуває лише на етапі формування національної моделі альтернативного вирішення правових спорів. На відміну від СС та США (Погоджувальний регламент ЮНСІТРАЛ 1980 р., Типовий закон ЮНСІТРАЛ про міжнародну комерційну погоджувальну процедуру 2002 р., Регламент дружнього врегулювання спорів МТП 2012 р., Правила МТП для інших видів АВС тощо), в країні існують поки лише проекти спеціальних законів. Інститут АВC може ефективно застосовуватись для вирішення правових конфліктів в нашій державі за умови їх формалізованої законодавчої регламентації на рівні галузевих законів 3 чітким механізмом регулювання альтернативних інститутів.

\section{Література:}

1. Гойко О. Від судового захисту до альтернативних методів вирішенню спорів. / О. Гойко // Теорія і практика інтелектуальної власності. - 2020.-№ 6 (56). - С. $54-60$.

2. Інтернет ресурс: https://pidru4niki.com/1513061656836/pravo/ alternativne_virishennya_sporiv

3. Худойкіна Т. В., Брижинський А. А. Проблеми і перспективи розвитку медіації // Правова політика та правове життя. -2019. C. $105-126$. 